\title{
Genetic past, present, and future of the honey bee (Apis mellifera) in the United States of America
}

\author{
Madeline H. CARPEnTER, Brock A. HARPUR \\ Department of Entomology, Purdue University, West Lafayette, IN, USA
}

Received 2 July 2020 - Revised 27 November 2020 - Accepted 15 December 2020

\begin{abstract}
Humans have domesticated hundreds of animal and plant species for thousands of years. Artwork, archeological finds, recorded accounts, and other primary sources can provide glimpses into the historic management practices used over the course of a given species' domestication history. Pairing historic data with newly available genomic data can allow us to identify where and how species were moved out of their native ranges, how gene flow may have occurred between distantly related populations, and quantify how selection and drift each contributed to levels of genetic diversity. Intersecting these approaches has greatly improved our understanding of many managed species; however, there has yet to be a thorough review in a managed insect. Here, we review the archival and genetic history of honey bees introduced to the mainland United States to reconstruct a comprehensive importation history. We find that since 1622, at least nine honey bee subspecies were imported from four of the five honey bee lineages and distributed en masse across the country. Many imported genotypes have genetic evidence of persisting today and may segregate non-randomly across the country. However, honey bee population genetic comparisons on the nationwide scale are not yet feasible because of gaps in genetic and archival records. We conclude by suggesting future avenues of research in both fields.
\end{abstract}

\section{population genomics / invasive species / archives / apiculture / admixture}

\section{INTRODUCTION}

Humans have intentionally managed animal and plant species around the world for over 15,000 years (Frantz et al. 2020; Larson and Fuller 2014). In some cases, management created subsets of the original population containing unique phenotypes and genotypes, i.e., domesticates. Archeological and archival evidence of domestication, where it exists, is an important source of specific migration, importation, or crossbreeding events; domestication centers; and morphological intermediates in the

Corresponding author: M. Carpenter,

carpe121@purdue.edu;

B. Harpur, bharpur@purdue.eduA. Harpur,

bharpur@purdue.edu

This article is part of the Topical Collection on the

Apidologie 50 Years

Manuscript editor: Klaus Hartfelder domestication process (Frantz et al. 2020; Larson et al. 2012; Zeder et al. 2006). However, reconstructing a complete domestication history from records alone is challenging. Modern genomics can address this gap by retroactively piecing together the demographic histories and phenotypic diversity of domesticate populations (Alberto et al. 2018; Braud et al. 2017; Meyer and Purugganan 2013; Sanchez et al. 2016).

The Western honey bee (Apis mellifera L.; henceforth "honey bee") is one of the few intensely managed insect species in the world. Humans have managed them for nearly 11,000 years for wax, honey, and - more recently - pollination (Batra 1995; Bloch et al. 2010; Crane 1999; RoffetSalque et al. 2015). As such, we have a detailed historic account of the natural and management histories of honey bees around the world (Crane 1999; Ruttner 1988). The honey bee's native range 
extends across Africa, Asia, and Europe, and is divided into at least five morphometrically, phenotypically, and genetically distinct lineages: A (Africa), M (northern Europe and central Asia), C (central and southern Europe), O (Middle East and western Asia), and Y (Arabian Peninsula and Ethiopian highlands) (Cridland et al. 2017; Han et al. 2012; Miguel et al. 2011; Ruttner 1988; Ruttner et al. 1978; Whitfield et al. 2006). Initially, these lineages were defined morphologically (Ruttner 1988) and were later supported by mitochondrial DNA (mtDNA) (Arias and Sheppard 1996; Cornuet and Garnery 1991; Crozier et al. 1989; Crozier and Crozier 1993; Garnery et al. 1992). Each lineage has unique mitochondrial haplotypes (mitotypes) with an average divergence of $2.5 \%$ between $\mathrm{A}, \mathrm{C}$, and $\mathrm{M}$ lineages (Garnery et al. 1992). Microsatellites further supported the mitochondrial and morphological groupings (Estoup et al. 1995; Garnery et al. 1998; Solignac et al. 2003). Most recently, genome-wide analysis taking advantage of the released honey bee genome (The Honeybee Genome Sequencing Consortium 2006) supported the five lineage models (Han et al. 2012; Whitfield et al. 2006). Average genome-wide differentiation (measured by $\mathrm{F}_{\mathrm{ST}}$ ) among lineages ranges from 0.3 to 0.6 (Cridland et al. 2017; Harpur et al. 2014; Miguel et al. 2011; Wallberg et al. 2014). Each lineage can further be divided into several subspecies by the same mitochondrial, whole genome, and microsatellite metrics; presently, twenty-nine subspecies are recognized. Average $\mathrm{F}_{\mathrm{ST}}$ between subspecies within the same lineage is smaller than between lineages (Wallberg et al. 2014); A. m. ligustica and A. m. carnica, both $C$ lineage honey bees, have an $\mathrm{F}_{\mathrm{ST}}$ of 0.06 (Dall'Olio et al. 2007).

Today, the honey bee can be found in introduced populations in western Asia, North America, South America, and Australia, to name a few. Across this new range, beekeepers have imported honey bees from multiple lineages, subjected them to selective breeding, and allowed them to escape and spread, resulting in admixed populations that exist in both managed and feral states (Chapman et al. 2008, 2019; Harpur et al. 2015; Oldroyd et al. 1997; Rivera-Marchand et al. 2008; Seeley 2007; Smith 1991). In the United States of America, at least nine honey bee subspecies have been introduced since 1622 (as we review below). Today, both feral and managed honey bees can be found throughout the country in admixed populations. As the United States of America covers over $9,800,000 \mathrm{~km}^{2}$ and exhibits considerable variation in climate, geography, honey bee importation history, and honey bee management practices, we predict the country contains a highly diverse population of honey bees.

Understanding honey bee genetics and population structure is vital to understanding and maintaining genetic diversity (Bohling et al. 2016; Brito et al. 2017; Harpur et al. 2012, 2015), discovering loci contributing variation to desirable traits (Bolormaa et al. 2017; Harpur et al. 2019), and ultimately developing breeding programs (Dekkers 2012; Jarquín et al. 2014). Fortunately, the USA has a detailed archival record (Crane 1999; Horn 2005; Oertel 1976a, b, c, d, e; Pellett 1938; Sheppard 1989a, b) and there is a growing number of genetic analyses of honey bee populations (Bozek et al. 2018; Calfee et al. 2020; Cleary et al. 2018; Coulson et al. 2005; Cridland et al. 2018; Darger 2013; Delaney et al. 2009; Kono and Kohn 2015; Magnus et al. 2011, 2014; Magnus and Szalanski 2010; Mikheyev et al. 2015; Pinto et al. 2004, 2007; Rangel et al. 2016, 2020; Schiff and Sheppard 1993, 1995, 1996; Schiff et al. 1994; Seeley et al. 2015; Szalanski et al. 2016a, b; Szalanski and Magnus 2010). Here, we synthesize and review historic records (Table S1, S2) and available genetic data sets (Table S3) to understand how management practices have influenced genetic diversity and differentiation of honey bee populations across the United States of America (USA). The confluence of these data sets allows us to propose novel hypotheses and frame honey bee management in the USA in the context of domestication genetics.

\section{THE HISTORY OF HONEY BEE IMPORTATION, EXPANSION, AND INVASION INTO THE UNITED STATES OF AMERICA}

Honey bees have been continually imported into the United States of America since 1622 (Table S1). The earliest known record refers to English "dark bees" (M lineage: Apis mellifera 
mellifera) which were imported by colonists to Jamestown, VA (Table S1; Fig. 1). The available records from 1622 to 1859 mention only two other recorded importations of honey bees to the United States of America until 1859: Mobile, AL (1773) (Oertel 1976b) and Pensacola, FL (1763) (Crane 1999; Pellett 1938). Two additional importations - to Plymouth, MA in the 1630s and Long Island, NY in the 1670s - are implied by historical records; both locations recorded honey bees sooner than would be expected had they moved by natural swarming (Fig. 1). Records suggest that $A$. $m$. mellifera was the only subspecies present in North America until the 1850s (Table S1).

A. m. mellifera colonies radiated out from their introduction sites on the East Coast by swarming and with beekeeper assistance. By the 1700s, "bee trees" were found throughout the Carolinas and Pennsylvania (Crane 1999; Horn 2005; Oertel 1976c). Honey bees could be found on the west bank of the Mississippi River by 1790 (Crosby and Worster 2004) and continued to spread across the Great Plains during the nineteenth century (Fig. 1, Table S2) (Crane 1999; Horn 2005; Oertel 1976b, d; Pellett 1938). During the 1850s, colonists introduced colonies to the Pacific Coast. Over three hundred A. m. mellifera colonies were shipped from New York, Pennsylvania, and Michigan to central California between 1852 and 1860 (Crane 1999; Harbison 1919; Pellett 1938; Watkins 1967, 1968a, b), establishing a founder population for further introductions to Hawaii in 1857 (Hopkins 1857), Washington in 1856 (Watkins 1968b), Nevada in 1852, and Southern California in 1862 (Fox 1878; Handy 1872; Horn 2005).

The second subspecies introduced to the United States of America was the Italian honey bee (C lineage: A. m. ligustica), which was initially sourced from exported populations in Tambaschoff, Germany, and Tamins, Switzerland (Table S1) (Benton 1892; Mahan 1861; Watkins 1968c). Later, American beekeepers imported A. $m$. ligustica queens directly from northern Italy, favoring the Lake Maggiore region in the 1860s (Langstroth 1866a) and Milan and Bologna in the 1890s (Benton 1892; Robinson 1892). During the 1860 s and 1870 s, honey bee queen suppliers established themselves throughout the United States of America by providing imported or open-mated A. m. ligustica queens to beekeepers across the country. Their actions spread A. m. ligustica from Vermont to California ( $2500 \mathrm{~km}$ ) within 10 years of introduction (Table S1; S2) (Fox 1878; Langstroth 1881; Pellett 1938). While we do not know the exact number of queens nor colonies imported, the available data suggests it was likely in the thousands. One importer, Charles Dadant, is reported to have introduced "hundreds [of $A$. m. ligustica queens] ... each year for several years" beginning in 1874 with a single shipment of 400 queens (C. Dadant 1880; C. P. Dadant 1918) and another, A. I. Root, claimed to have introduced 50-75 queens per year from the late 1860s at least until 1899 (Root 1899).

The Carniolan honey bee (C lineage: $A . m$. carnica) was first imported to the United States of America from Dalmatia (modern day Croatia) in 1877 (C. Dadant 1877, 1878), with additional introductions occurring during and after the $1880 \mathrm{~s}$ (Fig. 2, Table S2). Two of the most prominent A. m. carnica importers were Frank Benton, an American honey bee scientist, and Henry Alley, a breeder based in Coleraine, MA. Alley chiefly imported the "Banat bee," which were A. m. carnica native to Banat, Hungary (Sheppard 1989a). Benton, who was living in Munich, Germany, sent A. m. carnica from the Austrian Alps to the United States of America from 1882 to 1892 (Benton 1881, 1892; Lyon 1905). A. m. carnica was a popular subspecies in the late 1880s; based on queen supplier ads, A. m. carnica was widespread across the United States of America by 1900 (Table S1; S2). Benton continued to import A. m. carnica queens to the USDA experimental apiary in Maryland until the early 1900s (Benton 1910).

Beekeepers from New York State imported Caucasian honey bees (O lineage: A. m. caucasica) as early as 1882 (Houck 1883; Tefft 1890). One beekeeper reported sourcing them from extant populations in Germany (Houck 1883). However, A. m. caucasica did not become widespread until the early 1900 s. In 1902, Benton imported three A. m. caucasica queens from the shores of the Black and Caspian 


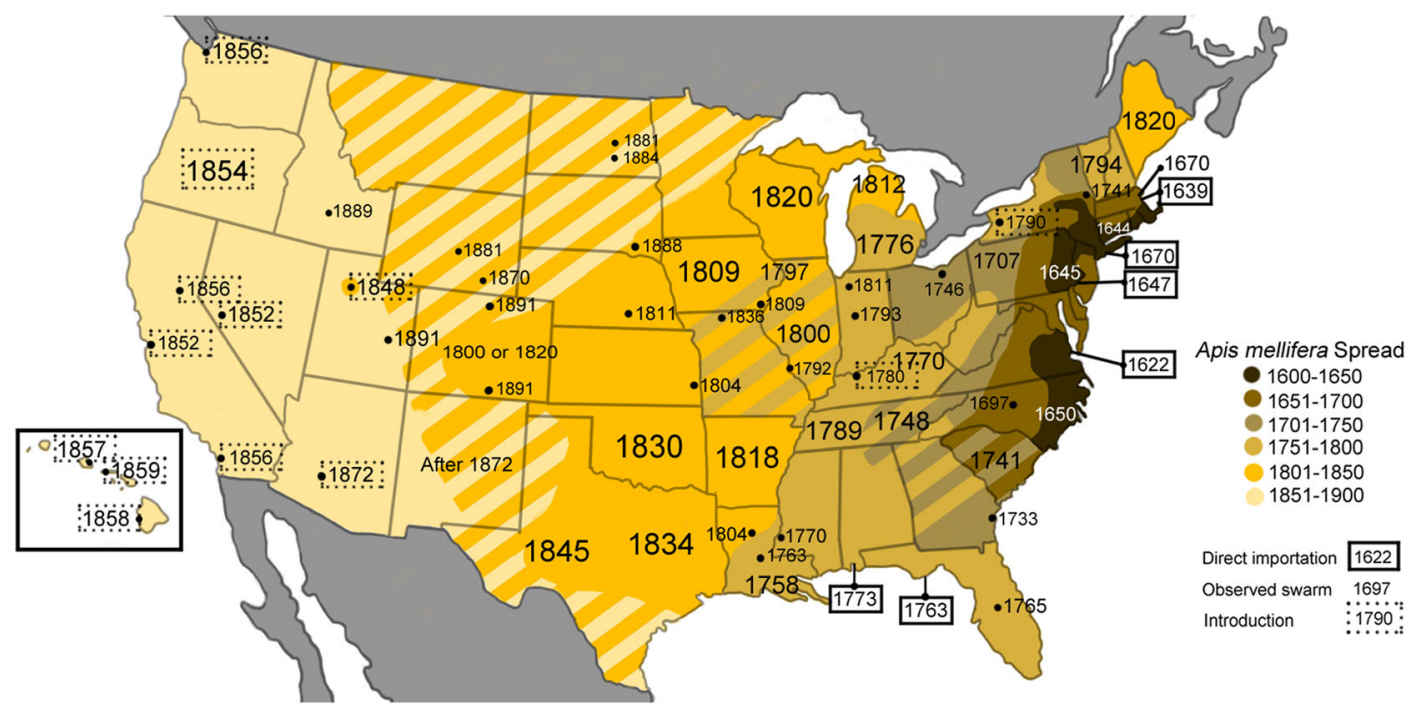

Figure 1. Estimated A. mellifera population expansions in the mainland United States. Locations have been recorded or estimated from digitized importation records of European colonialists or their accounts of swarm sightings. Sightings are given a specific location if possible; otherwise, the date text is larger and imposed over the state or area the sighting occurred (Table S1). Color gradients are proposed ranges estimated by combining known sightings and introductions with an estimation of average yearly spread as (50 years - establishment date) $\times 16.5 \mathrm{~km}$. Alaska has been excluded because honey bees were first introduced to the state in 1924 and cannot be attributed to a source population (Table S2). Dates before 1859 are exclusively A. m. mellifera sightings, but dates after 1859 can be attributed to A. m. ligustica, A. m. mellifera, A. m. ligustica x A. m. mellifera hybrids, and/or various A. mellifera hybrids.

Seas (Benton 1905, 1906; Lyon 1905) and in 1905 , he sourced an unknown number of queens from Russia (Table S1). He used both importations as a nucleus for a breeding program based in Beltsville, Maryland, from which he claims to have distributed at least $2000 \mathrm{~A}$. m. caucasica queens to beekeepers across the United States of America in 1905 alone (Table S2) (Lyon 1905; Phillips 1906). There were other $A . m$. caucasica importers operating both before and simultaneous to Benton (Table S1). Political unrest in the Caucasus Mountains between 1890 and 1910 deterred or delayed at least two A. $m$. caucasica importers, suggesting importations were infrequent (Phillips 1906; Pratt 1905; Root 1915). Importations directly from the Caucasus region ended in 1913 with a final recorded importation to Texas (Table S1) (Wilder 1913).

Four additional subspecies have been documented being imported into the US - the Egyptian honey bee (A lineage: A. m. lamarckii), the
Cyprian honey bee (O lineage: $A$. $m$. cypria), the Syrian honey bee (O lineage: $A$. $m$. syriaca), and the Tellian honey bee (A lineage: $A . m$. intermissa _-but records suggest that they were not distributed as widely because they were prone to swarming, absconding, and defensive behavior (Benton 1892; Massie 1891; Root 1899). A. m. lamarckii was only introduced to three states between 1866 and 1869 (Table S1). At least four $A$. $m$. intermissa queens were sourced from Hallamshire, England, after being imported from Northern Africa (Table S1) (Pratt 1891). Their progeny was distributed to five states between 1891 and 1893 and no record of their sale or propagation exists afterward (Table S1). A. m. syriaca was spread across nine states between 1881 and 1905 from an unknown number of source queens (Table S1). A. m. cypria was imported across 13 states between 1880 and 1910 (Table S2). Several hundred queens were imported directly (and weekly from 1880 to 1882) from 


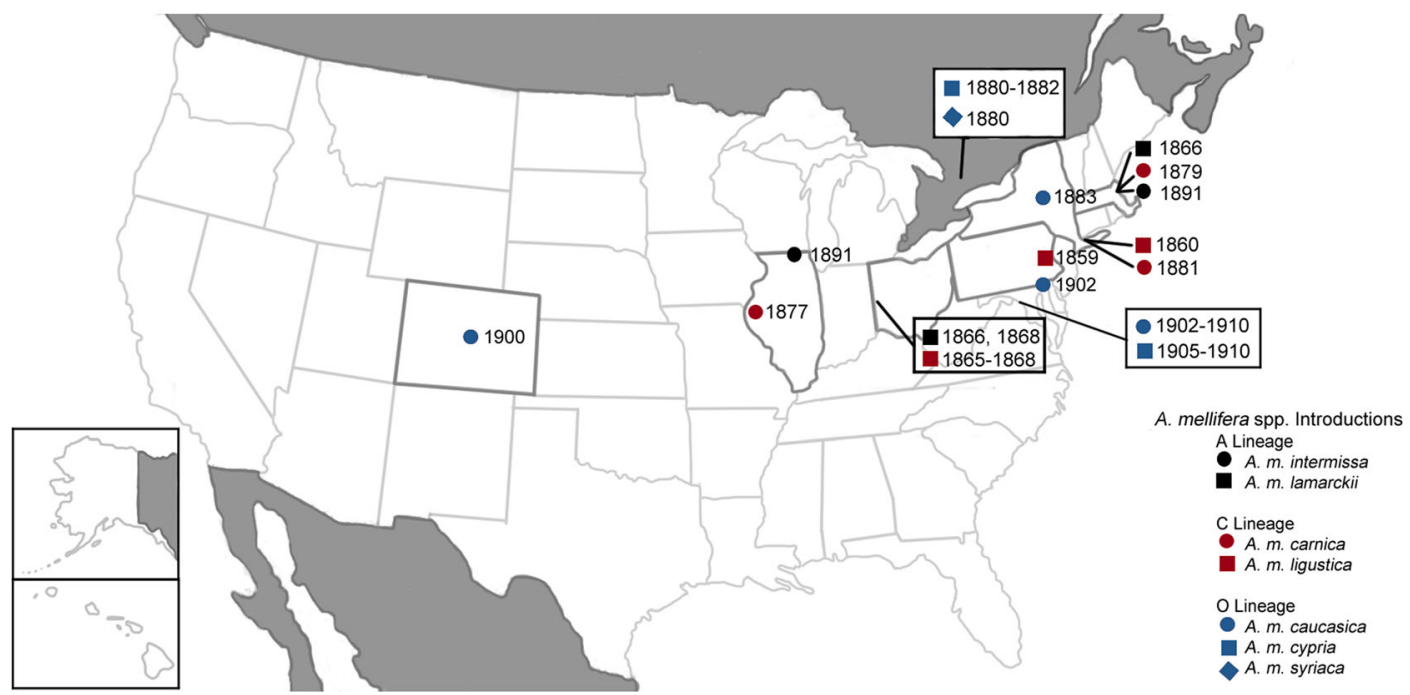

Figure 2. Seven subspecies were introduced to the mainland United States between 1859 and 1922: A. m. ligustica (1859), A. m. lamarckii (1866), A. m. carnica (1877), A. m. cypria (1880), A. m. syriaca (1880), A. m. caucasica (1882), and A. m. intermissa (1891) (Alley 1891; C. Dadant 1877; Houck 1883; Jones 1880a, 1880b, 1880c; Langstroth 1866b, 1881). Here, we have highlighted the first 5 years of a recorded importation of a given subspecies into the mainland United States. The exceptions are A. m. caucasica and A. m. cypria, both of which were imported sporadically or for a short time before importations ceased and were continued under Benton (see Table S1 for all importation records). One series of A. m. cypria and A. m. syriaca importations to Beeton (now New Tecumseth); Canada is recorded because these were the source of importations to the USA (Table S1) (Benton 1892; Jones 1880a). The boxes represent large-scale operations in Ohio (Rev. L. L. Langstroth); Washington, D.C. (Frank Benton); and Canada (D. A. Jones).

Cyprus (Table S1), beginning with an initial shipment of 150 queens to Jones' apiary in Beeton (now New Tecumseth), Ontario (Jones 1880a). Importation from Cyprus ended in 1882 but some queen suppliers continued to offer Cyprian honey bees-presumably the descendants of directly imported queens - into the 1890s (Brown 1891; Guenther 1891). In the early 1900s, Benton was able to import additional $A$. $m$. cypria from Cyprus for breeding experiments and did so until his retirement in 1910 (Benton 1910; Lyon 1905).

Events of the 1910s lead to an overall reduction in number of reported honey bee importations and ultimately the creation of the Bee Act of 1922. World War I (1914-1918) and the Isle of Wight disease (1906-1916) both reduced the number of colonies coming from Europe (Root 1921; Walther 1915). The Isle of Wight disease was partially responsible for the Honey Bee Act of 1922, which forbade the importation of live honey bees and hive products in the USA
(Anonymous 1922). In the 1960s, the act was expanded to ban germplasm to prevent the spread of African-hybrid honey bees (also called "AHBs," "Africanized honey bees," or "killer bees") from South and Central America (Sheppard 2013). Importations from Canada continued until 1987 when unease over African-hybrid honey bees caused that country to close its borders (Winston 1992) until 2004 (Sheppard 2013). However, both before and after the 1922 ban was reworded, imports were made for experimental purposes (Table S1). The introduction of Varroa destructor in 1987 sparked a second wave of importation as Varroa -resistant strains from Europe were introduced to augment US breeding programs. Notably, A. m. carnica "Yugo" honey bees were imported from Hungary in 1989. A decade later, hundreds of Varroa tolerant hybrid queens from the Primorsky Region from eastern Russia were imported between 1997 and 2002 (Table S1). 
In 1990, the first African-hybrid honey bees (AHBs; also called Africanized honey bees) became established in the United States of America. AHBs are the descendants of 36 mated $A . m$. scutellata queens sourced from Tanzania and Transvaal, South Africa (Winston 1992). Their offspring mated with the Brazilian honey bee population (likely M lineage: A. m. iberiensis) (Crane 1999; Wallberg et al. 2014; Whitfield et al. 2006), escaped captivity, and spread north and south (Calfee et al. 2020; García et al. 2018; Winston 1992). Since 1990, AHBs have spread to ten states in the southern US states: Arizona, Arkansas, California, Florida, Louisiana, Oklahoma, Nevada, New Mexico, Texas, and Utah. Their spread, unlike that of the subspecies described above, has largely been accomplished by natural swarming and not beekeeping (Bozek et al. 2018; Cridland et al. 2018; Pinto et al. 2004).

In 2004, the United States of America initiated honey bee trade with New Zealand and Australia. Hundreds of thousands of colonies were imported from Australia alone between 2004 and 2010. Trade ceased with Australia in 2010 over concerns of importing Apis cerana (Sheppard 2013). Currently, the USA allows live honey bee importations from New Zealand and Canada, and germplasm importations from Australia, Bermuda, Canada, France, Great Britain, New Zealand, and Sweden (USDA n.d.). Germplasm from other sources can be used with USDA permission. Since 2009, there have been at least 11 importations of germplasm to Washington State from Germany (A. m. carnica, 2008, 2009), Italy (A. m. ligustica, 2008, 2009, 2010, 2012) (Cobey et al. 2015; Sheppard 2012), Georgia (A. m. caucasica, 2010, 2011) (Sheppard 2012), Slovenia (A. m. carnica, 2011) (Sheppard 2012), and Poland (A. m. carnica, 2018) (Cobey et al. 2019).

\section{UNRAVELLING HONEY BEE MANAGEMENT HISTORY IN THE AGE OF GENOMICS}

While this record, like any archeological record, is incomplete and contains several caveats (Supplemental text; Table S1), historic primary sources are informative to our understanding of honey bee demography, genetic diversity, and differentiation across the country. Above, we documented that, since 1622, at least nine honey bee subspecies have been imported from at least four of the five honey bee lineages. By most accounts, the imported honey bees were distributed en masse to beekeepers across the country (Table S1; S2), with some spread by swarming (Table S1; Fig. 1). These actions by beekeepers over the course of several hundred years have likely lead to a genetically diverse, highly admixed, and genetically structured population of honey bees across the country. We continue this review by intersecting the historic record we have compiled with the genetic studies performed in honey bee populations in the United States of America.

To our knowledge, there have been 23 population genetic studies in 22 US states that examined feral and/or managed honey bees (Fig. 3; Table S3). Most of these studies have focused on mtDNA and microsatellites with only four whole genome re-sequencing studies (Bozek et al. 2018; Calfee et al. 2020; Cridland et al. 2018; Mikheyev et al. 2015). Sample sizes have varied immensely. For example, most states have $<50$ honey bees sequenced, while California has 606 and Texas has 1022 (Table S3). The geographic area sampled during these studies has also been inconsistent. While Hawaii (Szalanski et al. 2016b), Utah (Cleary et al. 2018), and California (Cridland et al. 2018) have been sampled statewide, the honey bees of Powdermill Creek Nature Reserve $\left(4.5 \mathrm{~km}^{2}\right)$ (Rangel et al. 2020) and Arnot Forest $\left(17 \mathrm{~km}^{2}\right.$ ) (Seeley et al. 2015) are the only feral honey bees sampled from Pennsylvania (total land area $=119,280 \mathrm{~km}^{2}$ ) and New York (total land area $=141,300 \mathrm{~km}^{2}$ ), respectively.

\section{GENETIC DIVERSITY}

\subsection{Mitotypes from historically imported subspecies are still present in the United States of America}

Mitochondrial studies currently provide the broadest look at the genetic diversity of honey bees across the USA both because of the sheer number of such studies (Table S3) and because we have yet to 


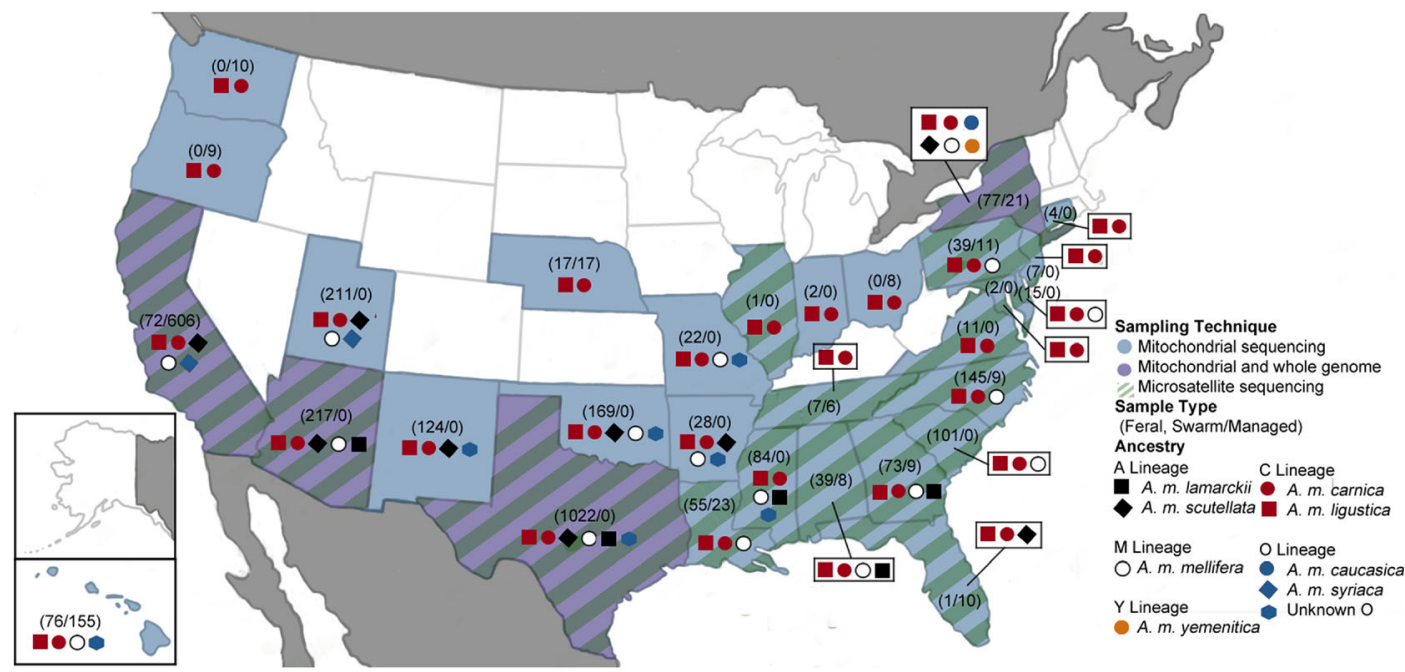

Figure 3. Summary of locations, methods, and sample sizes of honey bee genetic studies in the United States of America, as well as lineages or subspecies (when identifiable) detected. Both managed and feral populations are included in each state, but there is considerable — if not complete — overlap between lineages and/or mitotypes found within a state's feral and commercial colonies. The studies represented in this figure (as well as Table S3) specified the ancestry of individual samples. For example, Kono and Kohn (2015) used mtDNA to determine clines of A lineage in ancestry in California, but did not release specific mitotypes associated with each collected honey bee. Overall, the figure highlights two major shortcomings in US honey bee genomics: small sample sizes (11 states have fewer than 11 samples) and biases towards either managed or feral colonies within states. Furthermore, despite the documented presence of AHBs in Louisiana, Alabama, Mississippi, and Georgia, sampling methods have missed them here.

assemble genomic data for all honey bee subspecies. Genomic studies of honey bees in Africa and Asia are especially needed (Harpur et al. 2014; Wallberg et al. 2014). Mitochondrial studies have demonstrated that seven of the expected nine subspecies imported into the USA have mitotypes present within the USA today (Table S3; Fig. 3). The two most common mitotypes in the United States of America are $\mathrm{C} 1$ (A. m. ligustica) and C2 (A. m. carnica): $\mathrm{C} 1$ has been found in twenty-three states and $\mathrm{C} 2$ in sixteen (Table S3). Less common mitotypes that have been documented include those from $A . m$. lamarckii (Pinto et al. 2004, 2007; Rangel et al. 2016; Schiff and Sheppard 1993) and O2 from A. m. syriaca (Magnus et al. 2014), which were only briefly imported into the USA (Fig. 2). The A. $m$. lamarckii mitotype was reported in the southern states of Arizona, Texas, Mississippi, Alabama, and Georgia and the $\mathrm{O} 2$ mitotype - identical to a Lebanese A. m. syriaca mitotype (Magnus et al. 2014) — was found in Texas and California. Since there were no documented importations of $A . m$. syriaca since 1881 and $A$. m. lamarckii since 1869 (Table S1), these mitotypes may be remnants of the initial importations or more recent and unreported importations.

\subsection{Genomic data suggest high standing genetic diversity in US honey bees but cannot yet identify where that variation came from}

The number of mitotypes in the USA and the number of subspecies imported historically might suggest that the honey bees of the USA are highly genetically diverse. However, mitotypes alone tell an incomplete picture of how much genetic diversity exists in populations and honey bees in the USA have undergone at least three major bottlenecks as a result of pests and parasites (Horn 2005; Sanford 2001; vanEngelsdorp and Meixner 2010). A more complete picture can be made using the nuclear genome. The large number of independent markers used in analysis - up 
to several million for honey bees - provide accurate estimates of genetic diversity for colonies and populations, can increase the accuracy of ancestral sorting, and can allow one to tease apart the roles of demography and selection in contributing to genetic diversity in regions across the genome (Calfee et al. 2020; Cridland et al. 2018; Harpur et al. 2012; Mikheyev et al. 2015; Saelao et al. 2020; Wallberg et al. 2014). There have been five such studies focusing on honey bees in the mainland United States (Bozek et al. 2018; Calfee et al. 2020; Cridland et al. 2018; Mikheyev et al. 2015; Saelao et al. 2020) (Fig. 3).

These studies provide a glimpse at how historic importations may have impacted modern genetic diversity on a nationwide scale. Furthermore, when paired with additional genomic data from either museum specimens (Cridland et al. 2018; Mikheyev et al. 2015) or representatives from the honey bee's native range (Cridland et al. 2018; Harpur et al. 2014; Wallberg et al. 2014), it is possible to compare genetic diversity over space and time. One key takeaway from such studies to date is that genetic diversity within modern US populations is comparable to populations in the honey bee's native range. Californian non-AHB feral and commercial populations have genetic diversity similar to European $\mathrm{M}$ and $\mathrm{C}$ lineage source populations (Cridland et al. 2018); AHB have similar or greater genetic diversity compared to native A lineage honey bees (Bozek et al. 2018; Cridland et al. 2018); and within Texas and Arizona, genetic diversity increased following the introduction and spread of introgression with AHBs despite the loss of genetic diversity from Varroa (Bozek et al. 2018). Comparisons of genetic diversity of commonly used US commercial stocks to populations in Europe also suggest similar if not higher levels of genetic diversity (Saelao et al. 2020). This observation comes with several critical considerations. First, genetic comparisons between modern US honey bee populations and modern populations in the honey bee's native range occur over a spectrum of management intensities in both locations. Second, honey bees in their introduced range in the USA and their native range have experienced declines in genetic diversity due to Varroa mites (Bozek et al. 2018; Espregueira Themudo et al. 2020). Finally, only 13 honey bee subspecies have been sequenced to date (Chen et al. 2016; Haddad et al. 2018; Harpur et al. 2014; Wallberg et al. 2014, 2017; Wragg et al. 2018; Yunusbaev et al. 2019) and the sequencing has been performed using different sequencing technologies, complicating the direct comparison of data sets (Cridland et al. 2017). This has limited not only our ability to cleanly compare levels of genetic diversity but also our ability to estimate relatedness of samples in the USA to samples within the honey bee's native range. Where this has been done, US honey bees are related to the C, M, and A lineages (Bozek et al. 2018; Cridland et al. 2018; Mikheyev et al. 2015). While this supports some of the expectations of the historic record, the limited availability of genome sequence from honey bees within their native range and the limited sampling of honey bees within each lineage make it difficult to pinpoint precisely which subspecies is responsible for this relationship. More work in this field through careful sampling and comparison would be welcomed. The information gained is incredibly useful to our understanding of honey bee management history and a complete picture of the level of genome-wide genetic diversity and its distribution across management scenarios, and the landscape has yet to be put together.

\section{POPULATION STRUCTURE AND ANCESTRY}

\subsection{Genomic data provide evidence of population structure, the existence of feral populations, and variation in ancestry across the United States of America}

Differences in importation history and the extent of natural and artificial selection experienced by populations can contribute to genetic differentiation. Historic data suggest beekeepers readily shared material across the country and in great numbers, a pattern continued today. For example, a single queen supplier may rear thousands of 
queens from a single colony and disperse them across the country (Delaney et al. 2009). What does this mean for genetic differentiation? Are there distinct populations (e.g., East vs West; Feral vs Commercial) across the country or do honey bees form a single, contiguous population? How has selection shaped genetic differentiation in populations across the country?

Mitocondrial studies are, again, insightful. Clear differences in mtDNA haplotype frequency have been demonstrated between the Western and the Southeastern US (Delaney et al. 2009). Furthermore, mtDNA studies have suggested mitotype segregation by climate. $\mathrm{O} 2$ has been described as identical to a Lebanese $A . m$. syriaca mitotype (Magnus et al. 2014) and is found exclusively in states with mild winters (i.e., winter average temperatures above $12{ }^{\circ} \mathrm{C}$; California and Utah) (Cleary et al. 2018; Magnus et al. 2014). Similarly, A. m. lamarckii mitotypes have only been identified in Alabama, Mississippi, and Texas, three states with similarly mild winters (Pinto et al. 2004; Schiff and Sheppard 1993; Schiff et al. 1994). Historic records indicate that beekeepers were using A. m. syriaca in Los Angeles as early as 1881 (Osborn 1881), only a year after its initial importation into the country (Table S2). There may also be some structural differences between mainland and island portions of the US. Hawaiian honey bees do not contain unique mitotypes but as much as $35 \%$ of feral Hawaiian honey bees have M lineage mitotypes (Szalanski et al. 2016b), as compared to an estimated continental average of $7 \%$ (Magnus et al. 2014).

Nuclear genomic studies, though less extensive, suggest similar population structure across the country. In California, Avalon Island is significantly differentiated from mainland Californian populations (Cridland et al. 2018). Populations in Texas and Arizona are currently genetically distinct and have been even prior to the spread of AHB (Bozek et al. 2018). Recent work by Saelao et al. (2020) showed that there is some evidence of genetic differentiation among commonly used honey bee stocks. Given the limited spatial sampling of genomic studies so far (Fig. 3), more work is certainly needed to quantify and understand how distinct honey bee populations across the country are and what drives that distinction.

One important contributor to differentiation in the mainland US has been AHBs. The AHB invasion, unlike those of the managed honey bee subspecies above, has largely been accomplished by natural swarming (Bozek et al. 2018; Cridland et al. 2018; Pinto et al. 2004). AHBs are highly genetically distinct from other honey bees in the USA having both distinct mitotypes (Cleary et al. 2018; Darger 2013; Szalanski and Magnus 2010) and nuclear genomic variation (Kadri et al. 2016). Furthermore, AHBs have become established across much of the southern United States, where they demonstrate an ancestry cline between the previously introduced subspecies (largely $\mathrm{C}$ and M lineage, or "European honey bees") and A. $m$. scutellata. In California, average AHB ancestry is highest at the southern border and almost nonexistent $750 \mathrm{~km}$ away at $38^{\circ} \mathrm{N}$ latitude. The size and smoothness of this cline suggest there will not be a hard border between EHBs and AHBs, but rather a large hybrid zone extending hundreds of kilometers. Within this area, AHBs will exhibit a variety of intermediate phenotypes selected by climate variation (Calfee et al. 2020).

One particularly exciting avenue of exploration is identifying feral honey bee populations. Feral populations - defined here as a genetically distinct honey bee population living outside the confines of management - have existed historically in the United States of America but were thought to have been largely extirpated by Varroa (Kraus and Page 1995; Loper et al. 2006). However, feral populations likely still exist within the US. There is substantial evidence of mitotypes restricted to wild-caught colonies (Magnus and Szalanski 2010; Pinto et al. 2007; Schiff et al. 1994), variation in ancestry across the genome between wildcaught and nearby commercial colonies (Cridland et al. 2018; Kono and Kohn 2015; Mikheyev et al. 2015), and lower genetic diversity relative to nearby managed populations (Cridland et al. 2018; López-Uribe et al. 2017). In New York, feral honey bees collected in 2010 show greater similarity to honey bees collected in the same area 33 years previously than to modern commercial honey bees (Mikheyev et al. 2015). However, a 
microsatellite study examining feral and commercial honey bees from North Carolina found small but significant differentiation between the populations. The study concluded feral honey bees could be escapees from nearby managed colonies (López-Uribe et al. 2017). Therefore, significantly distinct feral colonies are not likely to exist everywhere. Instead, there may be a "hybridization zone" between managed and feral populations, as is the case when any domesticate is kept near its wild counterpart (Gering et al. 2015; Khosravi et al. 2013; Nussberger et al. 2013; Quilodrán et al. 2019), or when AHBs and preexisting honey bee populations collide (Calfee et al. 2020). Truly distinct feral colonies have been demonstrated to exist in wildlife refuges, teaching forests, remote islands, and other areas with little human habitation and no beekeeping (Bozek et al. 2018; Mikheyev et al. 2015). The number of such populations across the country, their origins, and how selection has shaped levels of genetic diversity are all significant outstanding questions.

\section{CONCLUSIONS AND THE FUTURE OF HONEY BEE POPULATION GENOMICS}

Despite the extensive sequencing efforts conducted to date (Table S3), many gaps in our knowledge still remain; these are highlighted even more when compared to the historic record. There are obvious gaps in sampling across the country. Almost all existing genetic studies have been conducted in the southern United States and therefore likely underestimate genetic diversity across the country (Fig. 3; Table S3). This is also true of honey bees in their native ranges: only 13 of 29 subspecies have been sequenced (Chen et al. 2016; Haddad et al. 2018; Wallberg et al. 2014, 2017; Wragg et al. 2018). This incomplete record - in both areas - prevents us from fully identifying the origins of haplotypes present within US populations. For example, several sources record the importation of $A$. m. intermissa (Pratt 1891) and A. m. cypria (Jones 1880c) (Table S1; $\mathrm{S} 2$ ), but neither mitochondrial nor nuclear DNA evidence has yet to verify them (Table S3). As well, the increased relatedness of New York feral colonies to A. m. yemenitica and A. m. scutellata in Mikheyev et al. (2015) despite a lack of historic record tying these subspecies to that location may indicate either an incomplete historic record or an incomplete set of reference genomes from honey bees within their native range. Expanding sequencing efforts across both the USA and the honey bee's native range would open the door for massive, continent-wide analyses of population structure, phylogeography, and local adaptation.

Given that beekeepers imported, distributed, and experimented with at least nine subspecies in the USA and some of these honey bees escaped and spread naturally, we predict that future genomic work will find that haplotypes originating from these introductions may contribute to phenotypic and genetic variation of honey bees in the US. We have yet to fully explore how much genomic variation from introduced subspecies is still present in US honey bees. We may expect some of those haplotypes to be segregating today as a result of selection or drift. How these haplotypes segregate across the country, where they originated from, and how they contribute to phenotypic variation are all questions still left to be answered. Recent population genomic studies have already begun to show how haplotypes of different origin may contribute to phenotypic variation in admixed populations. In Puerto Rico, haplotypes originating from $\mathrm{C}$ lineage populations are likely contributing to reduced defense response in AHBs (Avalos et al. 2014). There is similar evidence in Brazil for European haplotypes contributing to colony-level defense response (Harpur et al. 2020). In California, there is clear clinal variation in ancestry at specific regions of the genome that are maintained by selection (Calfee et al. 2020). We hypothesize that heritable phenotypes of economic value within the USA and other admixed honey bee populations around the world are likely underpinned by haplotypes originating from historic importations.

Honey bees stand at the unique juncture of wild and domesticated. Genomics is a versatile field suitable for studying honey bees in both capacities through further investigations into genetic diversity and selective pressures. However, genomics alone cannot unravel honey 
bees' complicated management history, especially in introduced ranges with rampant gene flow among disparate subspecies. Historical evidence can provide a scaffold for future hypotheses and vice versa; genomics can be used to support previous historical evidence or provide avenues for new studies.

\section{SUPPLEMENTARY INFORMATION}

The online version contains supplementary material available at https://doi.org/10.1007 /s13592-020-00836-4.

\section{ACKNOWLEDGMENTS}

The authors would like to thank the members of the Purdue Bee Lab, Margarita López-Uribe, Greg Hunt, Arian Avalos, and the talented staff at the Purdue University Archives and Special Collections for their informative discussions on this manuscript. We thank the reviewers for their kind and critical comments on an earlier version of this manuscript. We also thank Arian Avalos for sharing materials from the Oertel collections, without which this manuscript would not have been possible.

\section{AUTHORS' CONTRIBUTIONS}

MHC and BAH wrote the manuscript. MHC gathered review documents and assembled the figures and tables. This work was partly funded by the Eva Crane Trust and generous donations from the beekeepers of Indiana.

\section{DATA AVAILABILITY}

Not applicable.

\section{COMPLIANCE WITH ETHICAL STANDARDS}

Competing interests The authors declare that they have no competing interests.

Ethical approval Not applicable.

\section{OPEN ACCESS}

This article is licensed under a Creative Commons Attribution 4.0 International License, which permits use, sharing, adaptation, distribution and reproduction in any medium or format, as long as you give appropriate credit to the original author(s) and the source, provide a link to the Creative Commons licence, and indicate if changes were made. The images or other third party material in this article are included in the article's Creative Commons licence, unless indicated otherwise in a credit line to the material. If material is not included in the article's Creative Commons licence and your intended use is not permitted by statutory regulation or exceeds the permitted use, you will need to obtain permission directly from the copyright holder. To view a copy of this licence, visit http://creativecommons. org/licenses/by/4.0/.

Le passé, le présent et l'avenir génétiques de l'abeille (Apis mellifera) aux États-Unis.

génomique des populations / espèce invasive / agriculture / apiculture / mélange.

Die Vergangenheit, Gegenwart und Zukunft der Genetik der Honigbiene (Apis mellifera) in den Vereinigten Staaten.

Populationsgenomik / invasive Arten / Landwirtschaft / Bienenhaltung / genetische Rassenmischung.

\section{REFERENCES}

Alberto, F. J., Boyer, F., Orozco-terWengel, P., Streeter, I., Servin, B., de Villemereuil, P., Benjelloun, B., Librado, P., Biscarini, F., Colli, L., Barbato, M., Zamani, W., Alberti, A., Engelen, S., Stella, A., Joost, S., Ajmone-Marsan, P., Negrini, R., Orlando, L., ... Pompanon, F. (2018). Convergent genomic signatures of domestication in sheep and goats. Nature Coтmunications, 9(1), 1-9. https://doi.org/10.1038/s41467018-03206-y 
Alley, H. (1891). Punics! Apis Niger! Punics! American Bee Journal, 28 (4), 126.

Anonymous. (1922). The Isle of Wight Disease Bill. Gleanings in Bee Culture, 50 (6), 366-367.

Arias, M. C., \& Sheppard, W. S. (1996). Molecular Phylogenetics of Honey Bee Subspecies (Apis mellifera L.) Inferred from Mitochondrial DNA Sequence. Molecular Phylogenetics and Evolution, 5(3), 557-566. https://doi.org/10.1006/mpev.1996.0050

Avalos, A., Rodríguez-Cruz, Y., \& Giray, T. (2014). Individual responsiveness to shock and colony-level aggression in honey bees: Evidence for a genetic component. Behavioral Ecology and Sociobiology, 68(5), 761-771. https://doi.org/10.1007/s00265-014-1689-8

Batra, S. W. T. (1995). Bees and pollination in our changing environment. Apidologie, 26(5), 361-370. https://doi.org/10.1051/apido:19950501

Benton, F. (1881). The Bavarian Apiary. Gleanings in Bee Culture, 11 (7), 74.

Benton, F. (1892). Varieties of Bees and Their Characteristics. American Bee Journal, 31 (5), 142-148.

Benton, F. (1905). Caucasian Bees. American Bee Journal, $11(7), 74$.

Benton, F. (1906). 36th Annual Convention of the National Bee-Keepers' Association: Experimental Apiculture. American Bee Journal , 46 (31), 663-671.

Benton, F. (1910). Imported Queens. American Bee Journal, $50(1), 27$.

Bloch, G., Francoy, T. M., Wachtel, I., Panitz-Cohen, N., Fuchs, S., \& Mazar, A. (2010). Industrial apiculture in the Jordan valley during Biblical times with Anatolian honeybees. Proceedings of the National Academy of Sciences, 107 (25), 11240-11244. https://doi. org/10.1073/pnas.1003265107

Bohling, J., Haffray, P., \& Berrebi, P. (2016). Genetic diversity and population structure of domestic brown trout (Salmo trutta) in France. Aquaculture, 462, 1-9. https://doi.org/10.1016/j.aquaculture.2016.04.013

Bolormaa, S., Swan, A. A., Brown, D. J., Hatcher, S., Moghaddar, N., van der Werf, J. H., Goddard, M. E., \& Daetwyler, H. D. (2017). Multiple-trait QTL mapping and genomic prediction for wool traits in sheep. Genetics Selection Evolution, 49 (1), 62. https://doi. org/10.1186/s12711-017-0337-y

Bozek, K., Rangel, J., Arora, J., Tin, M., Crotteau, E., Loper, G., Fewell, J., \& Mikheyev, A. (2018). Parallel genomic evolution of parasite tolerance in wild honey bee populations . https://doi.org/10.1101/498436

Braud, M., Magee, D. A., Park, S. D. E., Sonstegard, T. S., Waters, S. M., MacHugh, D. E., \& Spillane, C. (2017). Genome-Wide microRNA Binding Site Variation between Extinct Wild Aurochs and Modern Cattle Identifies Candidate microRNA-Regulated Domestication Genes. Frontiers in Genetics, 8. https://doi. org/10.3389/fgene.2017.00003

Brito, L. F., McEwan, J. C., Miller, S. P., Pickering, N. K., Bain, W. E., Dodds, K. G., Schenkel, F. S., \& Clarke, S. M. (2017). Genetic diversity of a New Zealand multi-breed sheep population and composite breeds' history revealed by a high-density SNP chip. BMC Genetics , 18 (1), 25. https://doi.org/10.1186/s12863017-0492-8

Brown, H. H. (1891). My 23rd Annual Price List. American Bee Journal , 27 (19), 618.

Calfee, E., Agra, M. N., Palacio, M. A., Ramírez, S. R., \& Coop, G. (2020). Selection and hybridization shaped the rapid spread of African honey bee ancestry in the Americas. PLOS Genetics, 16 (10), e1009038. https://doi.org/10.1371/journal.pgen.1009038

Chapman, N. C., Lim, J., \& Oldroyd, B. P. (2008). Population Genetics of Commercial and Feral Honey Bees in Western Australia. Journal of Economic Entomology, 101 (2), 272-277. https://doi.org/10.1093 /jee/101.2.272

Chapman, N. C., Sheng, J., Lim, J., Malfroy, S. F., Harpur, B. A., Zayed, A., Allsopp, M. H., Rinderer, T. E., Roberts, J. M. K., Remnant, E. J., \& Oldroyd, B. P. (2019). Genetic origins of honey bees (Apis mellifera) on Kangaroo Island and Norfolk Island (Australia) and the Kingdom of Tonga. Apidologie, 50(1), 28-39. https://doi.org/10.1007/s13592-018-0615-x

Chen, C., Liu, Z., Pan, Q., Chen, X., Wang, H., Guo, H., Liu, S., Lu, H., Tian, S., Li, R., \& Shi, W. (2016). Genomic Analyses Reveal Demographic History and Temperate Adaptation of the Newly Discovered Honey Bee Subspecies Apis mellifera sinisxinyuan n. Ssp. Molecular Biology and Evolution, 33 (5), 1337-1348. https://doi.org/10.1093/molbev/msw017

Cleary, D., Szalanski, A. L., Trammel, C., Williams, M.-K., Tripodi, A., \& Downey, D. (2018). Mitochondrial DNA Variation of Feral Honey Bees (Apis mellifera L.) from Utah (USA). Journal of Apicultural Science, 62 (2), 223-232. https://doi.org/10.2478/jas-20180019

Cobey, S., Hopkins, B., \& Sheppard, W. S. (2015). Importation of Germplasm of Apis mellifera from Italy. American Bee Journal, 155 (4), 439-441.

Cobey, S., Bieńkowska, M., Wilde, J., \& Gąbka, J. (2019). Poland, the Only Country where Instrumentally Inseminated Queens are Routinely Used. American Bee Journal, 159 (3), 275-280.

Cornuet, J. M., \& Garnery, L. (1991). Mitochondrial DNA variability in honeybees and its phylogeographic implications. Apidologie, 22 (6), 627-642. https://doi. org/10.1051/apido:19910606

Coulson, R. N., Pinto, M. A., Tchakerian, M. D., Baum, K. A., Rubink, W. L., \& Johnston, J. S. (2005). Feral honey bees in pine forest landscapes of east Texas. Forest Ecology and Management, 215(1), 91-102. https://doi.org/10.1016/j.foreco.2005.05.005

Crane, E. (1999). The World History of Beekeeping and Honey Hunting . Routledge.

Cridland, J. M., Tsutsui, N. D., \& Ramírez, S. R. (2017). The Complex Demographic History and Evolutionary Origin of the Western Honey Bee, Apis mellifera. Genome Biology and Evolution, 9(2), 457-472. https://doi.org/10.1093/gbe/evx009 
Cridland, J. M., Ramirez, S. R., Dean, C. A., Sciligo, A., \& Tsutsui, N. D. (2018). Genome Sequencing of Museum Specimens Reveals Rapid Changes in the Genetic Composition of Honey Bees in California. Genome Biology and Evolution, 10(2), 458-472. https://doi. org/10.1093/gbe/evy007

Crosby, A. W., \& Worster, D. (2004). Ecological Imperialism: The Biological Expansion of Europe, 900-1900 (2nd ed.). Cambridge University Press.

Crozier, R. H., \& Crozier, Y. C. (1993). The mitochondrial genome of the honeybee Apis mellifera: Complete sequence and genome organization. Genetics, 133 (1), 97-117.

Crozier, R. H., Crozier, Y. C., \& Mackinlay, A. G. (1989). The CO-I and CO-II region of honeybee mitochondrial DNA: Evidence for variation in insect mitochondrial evolutionary rates. Molecular Biology and Evolution, 6 (4), 399-411. https://doi.org/10.1093 /oxfordjournals.molbev.a040553

Dadant, C. (1877). Cyprian and Carniolan Bees. American Bee Journal, 13 (1), 27.

Dadant, C. (1878). Editor Journal. American Bee Journal, $14(8), 282$.

Dadant, C. (1880). Dadant \& Son Colonies. American Bee Journal, 16(8), 398.

Dadant, C. P. (1918). The Italian Bee-History of Its Importation. American Bee Journal, 53 (12), 415-416.

Dall'Olio, R., Marino, A., Lodesani, M., \& Moritz, R. F. A. (2007). Genetic characterization of Italian honeybees, Apis mellifera ligustica, based on microsatellite DNA polymorphisms. Apidologie, 38(2), 207-217. https://doi.org/10.1051/apido:2006073

Darger, K. (2013). Determining Low Levels of Africanization in Unmanaged Honey Bee Colonies Using Three Diagnostic Techniques [M.S., University of Delaware]. http://udspace.udel.edu/bitstream/handle/19716 $/ 12667 /$ katherine_darger_thesis.pdf?sequence $=1$

C.M. J Dekkers (2012). Application of Genomics Tools to Animal Breeding. Current Genomics, 13 (3), 207212. https://doi.org/10.2174/138920212800543057

Delaney, D. A., Meixner, M. D., Schiff, N. M., \& Sheppard, W. S. (2009). Genetic Characterization of Commercial Honey Bee (Hymenoptera: Apidae) Populations in the United States by Using Mitochondrial and Microsatellite Markers. Annals of the Entomological Society of America , 102 (4), 666-673. https://doi. org/10.1603/008.102.0411

Espregueira Themudo, G., Rey-Iglesia, A., Robles Tascón, L., Bruun Jensen, A., da Fonseca, R. R., \& Campos, P. F. (2020). Declining genetic diversity of European honeybees along the twentieth century. Scientific Reports , 10(1), 10520. https://doi.org/10.1038/s41598020-67370-2

Estoup, A., Garnery, L., Solignac, M., \& Cornuet, J. M. (1995). Microsatellite variation in honey bee (Apis mellifera L.) populations: Hierarchical genetic structure and test of the infinite allele and stepwise mutation models. Genetics , 140 (2), 679-695.
Fox, C. J. (1878). The National Convocation: Bee-Keeping in California. American Bee Journal, 14 (12), 433435.

Frantz, L. A. F., Bradley, D. G., Larson, G., \& Orlando, L. (2020). Animal domestication in the era of ancient genomics. Nature Reviews Genetics, 1-12. https://doi.org/10.1038/s41576-020-0225-0

García, M. L. G., Reynaldi, F. J., \& Bravi, C. M. (2018). An update of Africanization in honey bee (Apis mellifera) populations in Buenos Aires, Argentina. Journal of Apicultural Research, 57(5), 611-614. https://doi. org/10.1080/00218839.2018.1494887

Garnery, L., Cornuet, J. M., \& Solignac, M. (1992). Evolutionary history of the honey bee Apis mellifera inferred from mitochondrial DNA analysis. Molecular Ecology, 1 (3), 145-154. https://doi.org/10.1111 j.1365-294X.1992.tb00170.x

Garnery, L., Franck, P., Baudry, E., Vautrin, D., Cornuet, J.-M., \& Solignac, M. (1998). Genetic diversity of the west European honey bee (Apis mellifera mellifera and A. m. Iberica). Genetics Selection Evolution, 30 (1), S49. https://doi.org/10.1186/1297-9686-30S1-S49

Gering, E., Johnsson, M., Willis, P., Getty, T., \& Wright, D. (2015). Mixed ancestry and admixture in Kauai's feral chickens: Invasion of domestic genes into ancient Red Junglefowl reservoirs. Molecular Ecology, 24 (9), 2112-2124. https://doi.org/10.1111/mec.13096

Guenther, J. (1891). Bee-keeping in Southern Wisconsin. American Bee Journal, 27 (19), 605.

Haddad, N. J., Adjlane, N., Saini, D., Menon, A., Krishnamurthy, V., Jonklaas, D., Tomkins, J. P., Loucif-Ayad, W., \& Horth, L. (2018). Wholegenome sequencing of north African honey bee Apis mellifera intermissa to assess its beneficial traits. Entomological Research, 48(3), 174-186. https://doi. org/10.1111/1748-5967.12272

Han, F., Wallberg, A., \& Webster, M. T. (2012). From where did the Western honeybee (Apis mellifera) originate? Ecology and Evolution, 2 (8), 1949-1957. https://doi.org/10.1002/ece3.312

Handy, J. S. (1872, July 27). The bees... The Arizona Citizen, 3.

Harbison, J. S. (1919). Introduction of the Honeybee to California. American Bee Journal, 59 (8), 268-270.

Harpur, B. A., Minaei, S., Kent, C. F., \& Zayed, A. (2012). Management increases genetic diversity of honey bees via admixture. Molecular Ecology, 21 (18), 44144421. https://doi.org/10.1111/j.1365-294 X.2012.05614.X

Harpur, B. A., Kent, C. F., Molodtsova, D., Lebon, J. M. D., Alqarni, A. S., Owayss, A. A., \& Zayed, A. (2014). Population genomics of the honey bee reveals strong signatures of positive selection on worker traits. Proceedings of the National Academy of Sciences, 111 (7), 2614-2619. https://doi.org/10.1073 /pnas.1315506111

Harpur, B. A., Chapman, N. C., Krimus, L., Maciukiewicz, P., Sandhu, V., Sood, K., Lim, J., Rinderer, T. E., 
Allsopp, M. H., Oldroyd, B. P., \& Zayed, A. (2015). Assessing patterns of admixture and ancestry in Canadian honey bees. Insectes Sociaux, 62 (4), 479-489. https://doi.org/10.1007/s00040-015-0427-1

Harpur, B. A., Guarna, M. M., Huxter, E., Higo, H., Moon, K.-M., Hoover, S. E., Ibrahim, A., Melathopoulos, A. P., Desai, S., Currie, R. W., Pernal, S. F., Foster, L. J., \& Zayed, A. (2019). Integrative Genomics Reveals the Genetics and Evolution of the Honey Bee's Social Immune System. Genome Biology and Evolution, 11 (3), 937-948. https://doi.org/10.1093/gbe/evz018

Harpur, B. A., Kadri, S. M., Orsi, R. O., Whitfield, C. W., \& Zayed, A. (2020). Defense Response in Brazilian Honey Bees (Apis mellifera scutellata $\times$ spp.) Is Underpinned by Complex Patterns of Admixture. Genome Biology and Evolution, 12 (8), 1367-1377. https://doi.org/10.1093/gbe/evaa128

Hopkins, C. G. (1857, November 7). At last the honey bees have been introduced here! The Polynesian, 5.

Horn, T. (2005). Bees in America. University Press of Kentucky.

Houck, T. (1883). North-eastern Bee-Keepers' Association. The Bee-Keeper's Exchange, 5 (3), 61-76.

Jarquín, D., Kocak, K., Posadas, L., Hyma, K., Jedlicka, J., Graef, G., \& Lorenz, A. (2014). Genotyping by sequencing for genomic prediction in a soybean breeding population. BMC Genomics, 15(1), 740. https://doi. org/10.1186/1471-2164-15-740

Jones, D. A. (1880a). Cyprian and Holy Bees, Etc. American Bee Journal, 16(12), 566-567.

Jones, D. A. (1880b). Editor's Omission. Gleanings in Bee Culture, $8(7), 448$.

Jones, D. A. (1880c). From Friends Jones and Benton. Gleanings in Bee Culture, 8 (7), 320-321.

Kadri, S. M., Harpur, B. A., Orsi, R. O., \& Zayed, A. (2016). A variant reference data set for the Africanized honeybee, Apis mellifera. Scientific Data, 3 (1), 160097. https://doi.org/10.1038/sdata.2016.97

Khosravi, R., Rezaei, H. R., \& Kaboli, M. (2013). Detecting Hybridization between Iranian Wild Wolf (Canis lupus pallipes ) and Free-Ranging Domestic Dog (Canis familiaris) by Analysis of Microsatellite Markers. Zoological Science, 30(1), 27-34. https://doi.org/10.2108/zsj.30.27

Kono, Y., \& Kohn, J. R. (2015). Range and Frequency of Africanized Honey Bees in California (USA). PLOS ONE, $10(9)$, e0137407. https://doi.org/10.1371/journal.pone.0137407

Kraus, B., \& Page, R. E. (1995). Effect of Varroa jacobsoni (Mesostigmata: Varroidae) on Feral Apis mellifera (Hymenoptera: Apidae) in California. Environmental Entomology, 24(6), 1473-1480. https://doi. org/10.1093/ee/24.6.1473

Langstroth, L. L. (1866a). A New Importation of Italian Queens, Direct from Italy. American Bee Journal, $2(2), 18$.

Langstroth, L. L. (1866b). Egyptian Queen Bees. American Bee Journal , 2 (5), 79.
Langstroth, L. L. (1881). Early Importations of Italian Bees. American Bee Journal, $17(11), 82$.

Larson, G., \& Fuller, D. Q. (2014). The Evolution of Animal Domestication. Annual Review of Ecology, Evolution, and Systematics, 45 (1), 115-136. https://doi.org/10.1146/annurev-ecolsys-110512135813

Larson, G., Karlsson, E. K., Perri, A., Webster, M. T., Ho, S. Y. W., Peters, J., Stahl, P. W., Piper, P. J., Lingaas, F., Fredholm, M., Comstock, K. E., Modiano, J. F., Schelling, C., Agoulnik, A. I., Leegwater, P. A., Dobney, K., Vigne, J.-D., Vilà, C., Andersson, L., \& Lindblad-Toh, K. (2012). Rethinking dog domestication by integrating genetics, archeology, and biogeography. Proceedings of the National Academy of Sciences , 109(23), 8878-8883. https://doi.org/10.1073 /pnas.1203005109

Loper, G., Sammataro, D., Finley-Short, J., \& Cole, J. (2006). Feral honey bees in southern Arizona, 10 years after Varroa infestation. American Bee Journal, $146(6), 521-524$.

López-Uribe, M. M., Appler, R. H., Youngsteadt, E., Dunn, R. R., Frank, S. D., \& Tarpy, D. R. (2017). Higher immunocompetence is associated with higher genetic diversity in feral honey bee colonies (Apis mellifera). Conservation Genetics, 18(3), 659-666. https://doi. org/10.1007/s10592-017-0942-x

Lyon, D. E. (1905). What is the U.S. Government Doing for Bee-Keeping? Gleanings in Bee Culture, 33 (16), 862-863.

Magnus, R. M., \& Szalanski, A. L. (2010). Genetic Evidence for Honey Bees (Apis mellifera L.) of Middle Eastern Lineage in the United States . 55 (1), 13.

Magnus, R. M., Tripodi, A. D., \& Szalanski, A. L. (2011). Mitochondrial DNA diversity of honey bees, Apis mellifera L. (Hymenoptera: Apidae) from queen breeders in the United States. Journal of Apicultural Science, 55 (1), 14.

Magnus, R. M., Tripodi, A. D., \& Szalanski, A. L. (2014). Mitochondrial DNA Diversity of Honey Bees (Apis mellifera) from Unmanaged Colonies and Swarms in the United States. Biochemical Genetics , 52 (5), 245257. https://doi.org/10.1007/s10528-014-9644-y

Mahan, P. J. (1861). Italian Bees, No Monopoly. American Bee Journal, 1 (6).

Massie, T. K. (1891). Two Punic Virgin Queens that "Turned Up Missing" Gleanings in Bee Culture, $19(23), 931$.

Meyer, R. S., \& Purugganan, M. D. (2013). Evolution of crop species: Genetics of domestication and diversification. Nature Reviews Genetics, 14 (12), 840-852. https://doi.org/10.1038/nrg3605

Miguel, I., Baylac, M., Iriondo, M., Manzano, C., Garnery, L., \& Estonba, A. (2011). Both geometric morphometric and microsatellite data consistently support the differentiation of the Apis mellifera M evolutionary branch. Apidologie, 42 (2), 150-161. https://doi. org/10.1051/apido/2010048 
Mikheyev, A., Tin, M. M. Y., Arora, J., \& Seeley, T. D. (2015). Museum samples reveal rapid evolution by wild honeybees exposed to novel parasite. Nature Communications, 6(7991).

Nussberger, B., Greminger, M. P., Grossen, C., Keller, L. F., \& Wandeler, P. (2013). Development of SNP markers identifying European wildcats, domestic cats, and their admixed progeny. Molecular Ecology Resources, 13 (3), 447-460. https://doi.org/10.1111 /1755-0998.12075

Oertel, E. (1976a). Bicentennial Bees: Early Records of Honey Bees in the Eastern United States. American Bee Journal , 115 (2), 70-71.

Oertel, E. (1976b). Bicentennial Bees: Early Records of Honey Bees in the Eastern United States. American Bee Journal, 116(3), 114, 128.

Oertel, E. (1976c). Bicentennial Bees: Early Records of Honey Bees in the Eastern United States. American Bee Journal, 116(4), 156-157.

Oertel, E. (1976d). Bicentennial Bees: Early Records of Honey Bees in the Eastern United States. American Bee Journal, 116 (5), 214-215.

Oertel, E. (1976e). Bicentennial Bees: Early Records of Honey Bees in the Eastern United States. American Bee Journal, 116 (6), 260-261.

Oldroyd, B. P., Thexton, E. G., Lawler, S. H., \& Crozier, R. H. (1997). Population demography of Australian feral bees (Apis mellifera). Oecologia, 111 (3), 381-387. https://doi.org/10.1007/s004420050249

Osborn, A. W. (1881). Cyprian and Palestine Bees. American Bee Journal, 17 (35), 277.

Pellett, F. C. (1938). The History of American Beekeeping . Collegiate Press, Inc.

Phillips, E. F. (1906). National at Chicago: Experimental Apiculture. American Bee Journal, 46 (31), 663-671.

Pinto, M. A., Rubink, W. L., Coulson, R. N., Patton, J. C., \& Johnston, J. S. (2004). Temporal Pattern of Africanization in a Feral Honeybee Population from Texas Inferred from Mitochondrial DNA. Evolution, 58(5), 1047-1055. https://doi.org/10.1111/j.00143820.2004.tb00438.x

Pinto, M. A., Sheppard, W. S., Johnston, J. S., Rubink, W. L., Coulson, R. N., Schiff, N. M., Kandemir, I., \& Patton, J. C. (2007). Honey Bees (Hymenoptera: Apidae) of African Origin Exist in Non-Africanized Areas of the Southern United States: Evidence from Mitochondrial DNA. Annals of the Entomological Society of America, 100 (2), 289-295. https://doi. org/10.1603/0013-8746(2007)100[289 :HBHAOA]2.0.CO;2

Pratt, E. L. (1891). Introducting the Punic Queen-Bee. American Bee Journal, 28 (2), 47-48.

Pratt, E. L. (1905). Caucasians. Gleanings in Bee Culture, 33 (24), 1345.

Quilodrán, C. S., Nussberger, B., Montoya-Burgos, J. I., \& Currat, M. (2019). Hybridization and introgression during density-dependent range expansion: European wildcats as a case study. Evolution, 73(4), 750-761. https://doi.org/10.1111/evo.13704

Rangel, J., Giresi, M., Pinto, M. A., Baum, K. A., Rubink, W. L., Coulson, R. N., \& Johnston, J. S. (2016). Africanization of a feral honey bee (Apis mellifera) population in South Texas: Does a decade make a difference? Ecology and Evolution, 6(7), 21582169. https://doi.org/10.1002/ece3.1974

Rangel, J., Traver, B., Stoner, M., Hatter, A., Trevelline, B., Garza, C., Shepherd, T., Seeley, T. D., \& Wenzel, J. (2020). Genetic diversity of wild and managed honey bees (Apis mellifera) in Southwestern Pennsylvania, and prevalence of the microsporidian gut pathogens Nosema ceranae and N. apis. Apidologie. https://doi. org/10.1007/s13592-020-00762-5

Rivera-Marchand, B., Keularts, J., Oskay, D., \& Giray, T. (2008). Coexistence of Feral Africanized and European Honey Bees (Hymenoptera: Apoidea: Apidae) on St. Croix Island. Caribbean Journal of Science, 44 (2), 264-266. https://doi.org/10.18475/cjos.v44i2.a18

Robinson, C. J. (1892). Bee and Honey in BeeTrees-Italians vs. Native Bees. American Bee Journal, 30 (22), 698.

Roffet-Salque, M., Regert, M., Evershed, R. P., Outram, A. K., Cramp, L. J. E., Decavallas, O., Dunne, J., Gerbault, P., Mileto, S., Mirabaud, S., Pääkkönen, M., Smyth, J., Šoberl, L., Whelton, H. L., Alday-Ruiz, A., Asplund, H., Bartkowiak, M., Bayer-Niemeier, E., Belhouchet, L., ... Zoughlami, J. (2015). Widespread exploitation of the honeybee by early Neolithic farmers. Nature, 527(7577), 226-230. https://doi. org/10.1038/nature 15757

Root, E. R. (1899). Ages at Which Queens Begin to Lay. Gleanings in Bee Culture, 27 (17), 641-642.

Root, E. R. (1915). Caucasians and Other Black Races Adapted to the South on Account of their Early Breeding. Gleanings in Bee Culture, 43 (5), 175.

Root, E. R. (1921). The Isle of Wight Disease Again. Gleanings in Bee Culture, 49 (6), 338-339.

Ruttner, F. (1988). Biogeography and Taxonomy of Honeybees. Springer-Verlag.

Ruttner, F., Tassencourt, L., \& Louveaux, J. (1978). Biometrical-Statistical Analysis of the Geographic Variability of Apis mellifera L. Apidologie, 9(4), 363-381. https://doi.org/10.1051/apido:19780408

Saelao, P., Simone-Finstrom, M., Avalos, A., Bilodeau, L., Danka, R., de Guzman, L., Rinkevich, F., \& Tokarz, P. (2020). Genome-wide patterns of differentiation within and among U.S. commercial honey bee stocks. BMC Genomics , 21 (1), 704. https://doi.org/10.1186 /s12864-020-07111-X

Sanchez, M. N., Brauning, R., Clarke, S. M., Nguyen, Q., McCulloch, A., Cockett, N. E., Zamani, W., Pompanon, F., Taberlet, P., McWilliam, S., Daetwyler, H., \& Kijas, J. (2016). Changing patterns of genomic variability following domestication of sheep. Journal of Animal Science, 94 (suppl_4), 13-13. https://doi. org/10.2527/jas2016.94supplement413x 
Sanford, M. T. (2001). Mites of the honey bee. Dadant and Sons .

Schiff, N. M., \& Sheppard, W. S. (1993). Mitochondrial DNA evidence for the 19th century introduction of African honey bees into the United States. Experientia , 49 (6), 530-532. https://doi.org/10.1007 /BF01955156

Schiff, N. M., \& Sheppard, W. S. (1995). Genetic Analysis of Commercial Honey Bees (Hymenoptera: Apidae) from the Southeastern United States. Journal of Economic Entomology, 88(5), 1216-1220. https://doi. org/10.1093/jee/88.5.1216

Schiff, N. M., \& Sheppard, W. S. (1996). Genetic differentiation in the queen breeding population of the western United States. Apidologie, 27(2), 77-86. https://doi. org/10.1051/apido:19960202

Schiff, Nathan M., Sheppard, W. S., Loper, G. M., \& Shimanuki, H. (1994). Genetic Diversity of Feral Honey Bee (Hymenoptera: Apidae) Populations in the Southern United States. Annals of the Entomological Society of America, 87 (6), 842-848. https://doi. org/10.1093/aesa/87.6.842

Seeley, T. D. (2007). Honey bees of the Arnot Forest: A population of feral colonies persisting with Varroa destructor in the northeastern United States. Apidologie, 38(1), 19-29. https://doi.org/10.1051 /apido:2006055

Seeley, T. D., Tarpy, D. R., Griffin, S. R., Carcione, A., \& Delaney, D. A. (2015). A survivor population of wild colonies of European honeybees in the northeastern United States: Investigating its genetic structure. Apidologie , 46(5), 654-666. https://doi.org/10.1007 /s13592-015-0355-0

Sheppard, W. S. (1989a). History of the Introduction of Honey Bee Races Into the United States. American Bee Journal, 129 (10), 664-666.

Sheppard, W. S. (1989b). History of the Introduction of the Honey Bee Races into the United States. American Bee Journal, 129(9), 617-619.

Sheppard, W. S. (2012, February). Honey Bee Genetic Diversity and Breeding: Towards the Reintroduction of European Germplasm . https://bee-health.extension. org/honey-bee-genetic-diversity-and-breeding:-towards-the-reintroduction-of-european-germplasm/

Sheppard, W. S. (2013). Managed Pollinator CAP: Germplasm for Honey Bee Breeding. Bee Culture, 141 (2), 24.

Smith, D. R. (1991). African bees in the Americas: Insights from biogeography and genetics. Trends in Ecology \& Evolution, 6(1), 17-21. https://doi.org/10.1016/01695347(91)90142-K

Solignac, M., Vautrin, D., Loiseau, A., Mougel, F., Baudry, E., Estoup, A., Garnery, L., Haberl, M., \& Cornuet, J.-M. (2003). Five hundred and fifty microsatellite markers for the study of the honeybee (Apis mellifera L.) genome. Molecular Ecology Notes, 3(2), 307-311. https://doi. org/10.1046/j.1471-8286.2003.00436.x

Szalanski, A. L., \& Magnus, R. M. (2010). Mitochondrial DNA characterization of Africanized honey bee (Apis mellifera L.) populations from the USA. Journal of Apicultural Research, 49 (2), 177-185. https://oi. org/10.3896/IBRA.1.49.2.06

Szalanski, A. L., Cleary, D., Trammel, C., \& Tripodi, A. D. (2016a). Genetic diversity, pathogens and parasites of feral honey bees and swarms from eight Mississippi counties. Midsouth Entomologist, 9, 67-76.

Szalanski, A. L., Tripodi, A. D., Trammel, C. E., \& Downey, D. (2016b). Mitochondrial DNA genetic diversity of honey bees, Apis mellifera, in Hawaii. Apidologie, 47(5), 679-687. https://doi.org/10.1007/s13592-0150416-4

Tefft, J. W. (1890). The Keeping of Bees and Their Improvement. American Bee Journal, 26(24), 399.

The Honeybee Genome Sequencing Consortium. (2006). Insights into social insects from the genome of the honeybee Apis mellifera. Nature, 443 (7114), 931949. https://doi.org/10.1038/nature05260

USDA. (n.d.). Honey Bees and Other Bees . USDA Animal and Plant Health Inspection Service. Retrieved November 7, 2019, from https://www.aphis.usda. gov/aphis/ourfocus/planthealth/importinformation/permits/plant-pests/sa_bees/honeybeesother

vanEngelsdorp, D., \& Meixner, M. D. (2010). A historical review of managed honey bee populations in Europe and the United States and the factors that may affect them. Journal of Invertebrate Pathology, 103 (Supplement), S80-S95.

Wallberg, A., Han, F., Wellhagen, G., Dahle, B., Kawata, M., Haddad, N., Simões, Z. L. P., Allsopp, M. H., Kandemir, I., Rúa, P. D. la, Pirk, C. W., \& Webster, M. T. (2014). A worldwide survey of genome sequence variation provides insight into the evolutionary history of the honeybee Apis mellifera. Nature Genetics , 46 (10), 1081-1088. https://doi.org/10.1038 /ng.3077

Wallberg, A., Schöning, C., Webster, M. T., \& Hasselmann, M. (2017). Two extended haplotype blocks are associated with adaptation to high altitude habitats in East African honey bees. PLOS Genetics, 13 (5), e1006792. https://doi.org/10.1371/journal. pgen. 1006792

Walther, J. (1915). The War and Swiss Beekeeping. American Bee Journal, 55 (2), $44-45$.

Watkins, L. H. (1967). Harbison's Second Importation of Bees to California. American Bee Journal, 107 (9), 378-379.

Watkins, L. H. (1968a). California's First Honey Bees. American Bee Journal, 108 (5), 190-191.

Watkins, L. H. (1968b). Mr. Buck's Importation of Bees to California. American Bee Journal, 108 (6), 232-233.

Watkins, L. H. (1968c). The Mahan-Parsons Italian Bee Controversy: A New Evaluation-Part I. American Bee Journal, 108 (11), 436-438.

Whitfield, C. W., Behura, S. K., Berlocher, S. H., Clark, A. G., Johnston, J. S., Sheppard, W. S., Smith, D. R., Suarez, A. V., Weaver, D., \& Tsutsui, N. D. (2006). Thrice Out of Africa: Ancient and Recent Expansions 
of the Honey Bee, Apis mellifera. Science, 314 (5799), 642-645. https://doi.org/10.1126/science.1132772

Wilder, J. J. (1913). More About Caucasian Bees. Gleanings in Bee Culture, 41 (10), 345-346.

Winston, M. L. (1992). Killer Bees: The Africanized Honey Bee in the Americas. Harvard University Press.

Wragg, D., Techer, M. A., Canale-Tabet, K., Basso, B., Bidanel, J.-P., Labarthe, E., Bouchez, O., Le Conte, Y., Clémencet, J., Delatte, H., \& Vignal, A. (2018). Autosomal and Mitochondrial Adaptation Following Admixture: A Case Study on the Honeybees of Reunion Island. Genome Biology and Evolution , 10 (1), 220 238. https://doi.org/10.1093/gbe/evx247

Yunusbaev, U. B., Kaskinova, M. D., Ilyasov, R. A., Gaifullina, L. R., Saltykova, E. S., \& Nikolenko, A.
G. (2019). The Role of Whole-Genome Studies in the Investigation of Honey Bee Biology. Russian Journal of Genetics, 55 (7), 815-824. https://doi.org/10.1134 /S102279541906019X

Zeder, M. A., Emshwiller, E., Smith, B. D., \& Bradley, D. G. (2006). Documenting domestication: The intersection of genetics and archaeology. Trends in Genetics, 22 (3), 139-155. https://doi.org/10.1016/j. tig.2006.01.007

Publisher's note Springer Nature remains neutral with regard to jurisdictional claims in published maps and institutional affiliations. 